\title{
ANALYSIS OF THE MICROSATELLITE VARIATION IN THE COMMON HYBRID BETWEEN RUSSIAN STURGEON (ACIPENSER GUELDENSTAEDTII BRANDT AND RATZEBURG, 1833) AND SIBERIAN STURGEON (ACIPENSER BAERII BRANDT, 1869) FROM AQUACULTURE
}

Sergiu GEORGESCU *, Oana CANAREICA *, Andreea DUDU * and Marieta COSTACHE *

* University of Bucharest, Faculty of Biology, Department of Biochemistry and Molecular Biology, Splaiul Independenţei 91-95, Bucharest, Sector 5, Romania, RO-050095, georgescu_se@yahoo.com, canareica_oana@yahoo.com,tn_andreea@yahoo.com, marietacostache@yahoo.com

DOI: 10.2478/trser-2013-0024

KEYWORDS: sturgeon, hybrid, microsatellite, aquaculture, genetic characterization. ABSTRACT

Sturgeons such as Acipenser baerii and Acipenser gueldenstaedtii are the most common species farm raised worldwide in aquaculture, because of the dwindling natural sources of caviar and meat. Also, these species can easily participate in the formation of an intraspecific hybrid with a great potential for growth in aquaculture.

Microsatellites are nuclear markers consisting of short repetitive sequence, dispersed across the entire genome with characteristics such as relatively small size and high level of polymorphism. The aims of the present study were to optimize a protocol for microsatellite multiplexing and analysis of genetic diversity in hybrid sturgeons farmed in Romania.

Genomic DNA was isolated from fins, and four pairs of primers were designed to amplify microsatellite loci: LS 19, LS 68, Aox 9, and Aox 45. Amplification of the microsatellite loci was carried out in one 3-Plex reaction for LS 19, LS 68, and Aox 9, and monoplex reaction for Aox 45. For an individual locus we obtained four alleles for Aox 45, eleven alleles for Aox 9, six alleles for LS 68, and eight alleles for LS 19. The results will be applied to test the broodstocks at Romanian hatcheries and to increase the efficiency of breeding.

RÉSUMÉ: Analyse de la variation des microsatellites de l'hybride commun d'aquaculture de l'esturgeon russe (Acipenser gueldenstaedtii) et de l'esturgeon sibérien (Acipenser baerii).

Les espèces d'esturgeons Acipenser baerii et Acipenser gueldenstaedtii sont parmi les plus communes dans l'aquaculture de monde entier suite de la diminution des ressources naturelles de caviar et de viande. De surcroît, ces espèces peuvent facilement participer à la formation d'un hybride intraspecifique possèdant un fort potentiel d'élevage.

Les microsatellites sont des marqueurs nucléaires représentés par des séquences répétitives courtes dispersées dans le génome entier et définit par une taille relativement petite ainsi qu'un haut niveau de polymorphisme. Le but de la présente étude est l'optimisation d'un protocole d'amplification de loci microsatellites par PCR multiplex et l'analyse de la diversité génétique des hybrides d'esturgeons d'aquaculture en Roumanie.

L’ADN génomique a été isolée à nageoire. Ainsi, quatre paires d'amorces on été utilisées pour amplifier les microsatellites LS 19, LS 68, Aox 9 et Aox 45. Une réaction d'amplification 3-Plex a été réalisée pour LS 19, LS 68 et Aox 9 ainsi qu'une monoplex pour Aox 45. Pour les loci individuels, nous avons obtenu quatre allèles pour Aox 45, onze allèles pour Aox 9, six allèles pour LS 68 et huit allèles pour LS 19. Le protocole sera appliqué afin de tester la pureté des stocks d’aquaculture des fermes piscicoles de la Roumanie et également pour augmenter l'efficacité de la reproduction. 
REZUMAT: Analiza variaţiei microsateliţilor la hibridul comun dintre nisetru (Acipenser gueldenstaedtii) şi sturionul siberian (Acipenser baerii) din acvacultură.

Sturionii precum Acipenser baerii şi Acipenser gueldenstaedtii sunt printre cele mai comune specii crescute în acvacultură, în întrega lumea datorită diminuării resurselor naturale de caviar şi carne. Totodată, aceste specii au o capacitate ridicată pentru a participa la formarea unui hibrid interspecific, cu un înalt potenţial pentru creşterea în acvacultură.

Microsateliţii sunt markeri nucleari reprezentaţi de secvenţe repetitive scurte, dispersate în întreg genomul, având caracteristici precum dimensiunile reduse şi un înalt nivel de polimorfism. Scopul prezentului studiu a fost optimizarea unui protocol de PCR multiplex pentru amplificarea de microsateliţi şi analiza diversităţii genetice a hibrizilor de sturioni crescuţi în condiţii de acvacultură în România.

ADN genomic a fost izolat din înotătoare şi patru perechi de primeri au fost desemnaţi pentru amplificarea microsateliţilor LS 19, LS 68, Aox 9 şi Aox 45. Amplificarea a fost realizată într-o reacţie 3-Plex pentru locii LS 19, LS 68 şi Aox 9 şi o reacţie monoplex pentru Aox 45. La nivelul locilor individuali, s-au obţinut four alele pentru Aox 45, unsprezece alele pentru Aox 9, şase alele pentru LS 68 şi opt alele pentru LS 19. Rezultatele vor fi utilizate pentru testarea purităţii stocurilor aparţinând crescătoriilor din România şi pentru creşterea eficienţei reproducerii.

\section{INTRODUCTION}

The Danube sturgeon species are among the most valuable species because there is high demand in the global market for both their meat and their roes (caviar). A special measure to develop the aquaculture system for sturgeons in Romania should be considered to reduce the pressure of overfishing and to continue the programs for populating the Danube River with sturgeon spawn. Nowadays, the order of Acipenseriformes counts 25 sturgeon and two paddlefish species, the majority being at the brink of extinction. Because of the commercial value of their roes (caviar), the sturgeon populations all over the world have been overexploited by fishing and poaching. The construction of dams and pollution completed the destructive effect of the anthropic intervention by affecting their habitat and, particularly, their breeding areas. Given their great value, there are many global concerns for sturgeons' protection. For conservation and restoration of sturgeon species, numerous measures have been taken both nationally and internationally. IUCN (International Union for Conservation of Nature) and CITES (Convention on International Trade in Endangered Species of Wild Fauna and Flora) listed acipenserids in their lists and appendices concerned with conserving threatened species. (Bemis et al., 1997)

The natural range of Siberian sturgeon, Acipenser baerii, is very large, the species being present in all hydrographic basins from Siberia, from the river basin of Ob-Irtych in North-West Siberia to the river basin of Kolyma in North-Est Siberia. A particular population of Siberian sturgeon is also present in the hydrographic system of the Baikal Lake. Thus, three subspecies have been distinguished for the Siberian sturgeon: Acipenser baerii baerii in the $\mathrm{Ob}$ river basin, Acipenser baerii stenorrhynchus starting with the Ienisseï River basin as far as the Kolyma River basin and Acipenser baerii baicalensis in the Baikal Lake system (Matallanas, 1997).

The farming of this species began in the former USSR in the 1970s and now the farming activities occur in many other countries from all continents. Rearing conditions in farms are most of the time more favorable than the natural conditions where they originate, and puberty occurs considerably earlier, at about six years old for the males and seven years old for the females (Matallanas, 1997). 
The species has also been the subject of various hybridizations. One of the species participating in the formation of hybrids with A. baerii is A. gueldenstaedtii and the new hybrid has a great potential for growth in aquaculture.

Acipenser gueldenstaedtii (Russian sturgeon) is an anadromous species. For breeding, the Russian sturgeons enter the rivers, far away from the mouth, in two migration periods: spring, to reproduce in the same year, and autumn, to reproduce the next spring (Oțel, 2007). A. gueldenstaedtii, as well as Huso huso or Acipenser stellatus, does not migrate every year for reproduction, but at intervals of two to five years. Currently, the species can be found along the Black Sea coast and the Danube River, from the mouth to the Iron Gate Dam, but in the past migrated near Budapest (Oțel, 2007). A. gueldenstaedtii, a species with 250 chromosomes, is considered to be, by the majority of the authors, a tetraploid species with an octaploid ancestor from which some microsatellite loci with octasomic profile are still maintained.

Microsatellites are nuclear markers consisting of a short repetitive sequence (2-9 bp), dispersed in the entire genome with characteristics such as relatively small size, easiness of amplification, codominant inheritance and high level of polymorphism. Such repetitions are highly variable, enabling that location to be tagged or used as a marker. Their advantages (high level of polymorphism, a higher power of discrimination comparative to other genetic markers, codominant mendelian inheritance) make microsatellite markers suitable for genetic research in wild and aquaculture stocks. Specific primers developed to amplify the microsatellite loci from one species can often lead to similar loci amplification of closely related species (Estoup and Angers, 1998), thus representing an advantage especially in small population analysis. The sturgeon studies based on analysis of microsatellite markers were started on North American species (McQuown et al., 2000; King et al., 2001; Pyatskowit et al., 2001; HendersonArzapalo and King, 2002; Welsh et al., 2003; Welsh and May, 2006; Fopp-Bayat, 2010) and now, many species have been studied in terms of genetic diversity, despite the difficulties of collecting biological samples reflected in the low number of individuals analyzed. For the European sturgeon species, genetic diversity studies were more limited. Initially, a number of species-specific microsatellites for Acipenser naccarii were developed in efforts to restore the species in Pad River (Italy), but loci analysis proved to be difficult due to the nature of this tetraploid species (Zane et al., 2002; Forlani et al., 2008). For Ponto-Caspian species such analyses were carried out less, the only significant studies using microsatellite markers were those concerning the population of A. stellatus from the Caspian Sea (Norouzi and Pourkazemi, 2009) and populations of A. gueldenstaedtii from the north-west of the Black Sea, the Northern part of the Caspian Sea and the Azov Sea (Timoshkina et al., 2009).

The major aim of the present study was the application of microsatellite DNA for analysis of genetic diversity in common hybrids between A. gueldenstaedtii and A. baerii, farmed at a hatchery in Romania. The results will be applied to test the purity of hatchery broodstocks at Romanian fish farms and to increase the efficiency of selective breeding and performance testing programs.

\section{MATERIAL AND METHODS}

\section{Sampling and DNA extraction}

Microsatellite loci were examined by using samples harvested without endangering the life of the individuals. Fin clips were collected from 25 hybrids (A. baerii x A. gueldenstaedtii) from a Romanian Fish Farm. Genomic DNA was extracted from fin tissue by phenolchloroform method with minor modifications (Taggart et al., 1992). 


\section{Microsatellite amplification}

For the microsatellite analysis we used four primer pairs to cross-amplify the following loci: LS 19, LS 68, Aox 9 and Aox 45. These primers were initially designed in North-American sturgeons (Tab. 1). Initially, the PCR conditions were optimized by varying the annealing temperature between $50-61^{\circ} \mathrm{C}$ on a gradient thermocycler IQCycler (BioRad). For the microsatellite loci detection we used the forward primers labeled with four different fluorescent dyes: PET, VIC, 6-FAM, NED (Tab. 1). Amplification of the microsatellite loci was done by one 3-Plex reaction for Aox 9, LS 19 and LS 68 and a monoplex reaction for Aox 45.

Table 1: Primer sequences for the microsatellites loci.

\begin{tabular}{|l|l|c|}
\hline Primer & Sequence & Species \\
\hline LS 19 F & 6-FAM-CATCTTAGCCGTCTGGGTAC & $\begin{array}{c}\text { Acipenser } \\
\text { fulvescens }\end{array}$ \\
LS 19 R & CAGGTCCCTAATACAATGGC & $\begin{array}{c}\text { Acipenser } \\
\text { fulvescens }\end{array}$ \\
\hline LS 68 F & NED-TTATTGCATGGTGTAGCTAAAC & $\begin{array}{c}\text { Acipenser } \\
\text { oxyrhinchus }\end{array}$ \\
\hline LS 68 R & AGCCCAACACAGACAATATC & $\begin{array}{c}\text { Acipenser } \\
\text { oxyrhinchus }\end{array}$ \\
\hline Aox 9 R & VIC-GATATTGGAGCTGTGCATTG & ACATTGTTTGGTAGGCCAGC \\
\hline Aox 45 F & PET-TTGTTCAATAGTTTCCAACGC & \\
Aox 45 R & TGTGCTCCTGCTTTTACTGTC & \\
\hline
\end{tabular}

PCRs were done in $25 \mu \mathrm{L}$ final volume with PCR Buffer, $\mathrm{MgCl}_{2}, 200 \mu \mathrm{M}$ of each nucleotide, DNA template, $0.3 \mu \mathrm{L}$ of each primer, two units of AmpliTaq Gold DNA Polymerase and nuclease free water. The 3-Plex reaction was carried out on GeneAmp 9700 PCR System (AppliedBiosystems) under the following conditions: initial denaturing step at $95^{\circ} \mathrm{C}$ for ten minutes, 35 cycles of denaturing for 30 seconds, $54^{\circ} \mathrm{C}$ annealing for 30 seconds, $72^{\circ} \mathrm{C}$ extension for 60 seconds; and a final extension at $72^{\circ} \mathrm{C}$ for 60 minutes. For the monoplex reaction we followed the same conditions, but the annealing step was at $47^{\circ} \mathrm{C}$. The amplified fragments were loaded with the GeneScan-500 LIZ Size Standard into ABI Prism 310 DNA Genetic Analyzer.

\section{Data analysis}

The results were analyzed with the GeneScan 3.1.2. and Genotyper 2.5.2. Softwares (AppliedBiosystems). The statistical analysis was done using the GENETIX software (Belkhir et al., 2002).

\section{RESULTS AND DISCUSSION}

Due to certain characteristics, for instance, polyploidy, the sturgeon species hybridize more easily than other fish species (Birstein et al., 1997). It is a well-known fact that sturgeons hybridize in natural conditions leading, sometimes, to fertile intergeneric or interspecific hybrids. In aquaculture the interspecific hybridization has been used to increase the growth rate and disease resistance, improve tolerance to environmental extremes and improve a variety of other traits that make aquatic animal production more profitable. 
The main limitation in microsatellite analysis in sturgeons is related to the complexity of their genome. Some authors consider that the sturgeon species with $\sim 120$ chromosomes such as A. stellatus, $H$. huso or A. ruthenus are tetraploids (Birstein et al., 1997), while these with $\sim 250$ chromosomes (e.g. A. gueldenstaedtii) are octaploids. Other authors consider that they are functional diploids, respectively tetraploids (Fontana et al., 1998; Tagliavini et al., 1999). The Siberian sturgeon belongs to the group of sturgeons with a chromosome number of around 250 (Birstein et al., 1997). The analysis of the genetic diversity highlights the relationships between individuals and may be a useful tool in directing specific crossbreeding. Measuring genetic diversity in wild fish populations or aquaculture stocks is essential for interpretation, understanding and effectively managing these populations or stocks.

Table 2: Characteristics of the microsatellite loci.

\begin{tabular}{|c|c|c|c|}
\hline Locus & Size (bp) & Number of alleles & Pattern \\
\hline LS 19 & $118-145$ & 8 & Polysomic \\
\hline LS 68 & $200-252$ & 6 & Polysomic \\
\hline Aox 9 & $194-246$ & 11 & Polysomic \\
\hline Aox 45 & $132-236$ & 4 & Polysomic \\
\hline
\end{tabular}

In our study, we have successfully amplified all four microsatellite loci for all the hybrids. The size of the alleles and the pattern of each locus are presented in table number 2 .

Genotypes were determined for all individuals. The number of allele peaks depends on the level of ploidy of the analyzed species and on whether the individual tested is heterozygote or homozygote. The size of the alleles at individual loci varied between 118 and $252 \mathrm{bp}$. A medium level of polymorphism was observed for the population of hybrids studied. Four to 11 alleles where observed with an average of 7.25 alleles per locus. The most polymorphic locus is Aox 9. Aox 45 or LS 68 presents a lower polymorphism in the population. All four loci presented a polysomic profile. The size of the alleles and the pattern of each locus are shown in table number 3.

Table 3: Allele frequencies for the microsatellite loci.

\begin{tabular}{|l|l|l|l|l|l|l|l|}
\hline $\begin{array}{l}\text { LS 19/ } \\
\text { Allele }\end{array}$ & Frequencies & $\begin{array}{l}\text { LS 68/ } \\
\text { Allele }\end{array}$ & Frequencies & $\begin{array}{l}\text { Aox 9/ } \\
\text { Allele }\end{array}$ & Frequencies & $\begin{array}{l}\text { Aox 45/ } \\
\text { Allele }\end{array}$ & Frequencies \\
\hline $\mathbf{1 1 8}$ & 0.0714 & $\mathbf{1 2 8}$ & 0.1111 & $\mathbf{1 9 4}$ & 0.0870 & $\mathbf{1 3 2}$ & 0.2500 \\
\hline $\mathbf{1 2 4}$ & 0.0238 & $\mathbf{1 4 8}$ & 0.2500 & $\mathbf{1 9 6}$ & 0.0435 & $\mathbf{1 5 3}$ & 0.2500 \\
\hline $\mathbf{1 2 7}$ & 0.1905 & $\mathbf{2 0 0}$ & 0.1111 & $\mathbf{2 0 8}$ & 0.1522 & $\mathbf{2 3 3}$ & 0.2500 \\
\hline $\mathbf{1 3 0}$ & 0.1905 & $\mathbf{2 2 8}$ & 0.1389 & $\mathbf{2 1 4}$ & 0.0652 & $\mathbf{2 3 6}$ & 0.2500 \\
\hline $\mathbf{1 3 3}$ & 0.1905 & $\mathbf{2 3 2}$ & 0.1667 & $\mathbf{2 1 8}$ & 0.0870 & & \\
\hline $\mathbf{1 3 6}$ & 0.0476 & $\mathbf{2 4 8}$ & 0.1111 & $\mathbf{2 2 2}$ & 0.1739 & & \\
\hline $\mathbf{1 4 2}$ & 0.1429 & $\mathbf{2 5 2}$ & 0.1111 & $\mathbf{2 2 6}$ & 0.0652 & & \\
\hline $\mathbf{1 4 5}$ & 0.1429 & & & $\mathbf{2 2 8}$ & 0.0217 & & \\
\hline & & & & $\mathbf{2 4 0}$ & 0.1087 & & \\
\hline & & & & $\mathbf{2 4 2}$ & 0.0652 & & \\
\hline & & & & $\mathbf{2 4 6}$ & 0.1304 & & \\
\hline
\end{tabular}

Examples of electrophoregrams for the hybrid specific loci are shown in figures 1-4. 


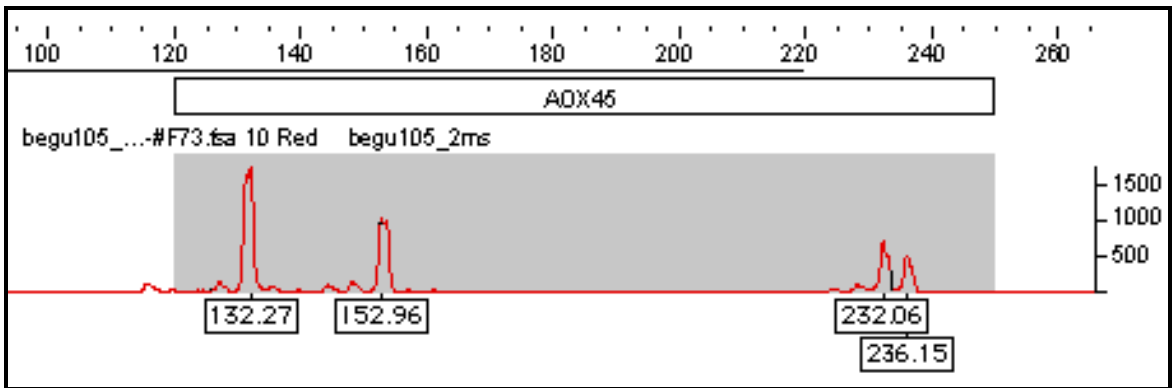

Figure 1: Genotyper software analysis of PCR amplification product for Aox 45 microsatellite locus.

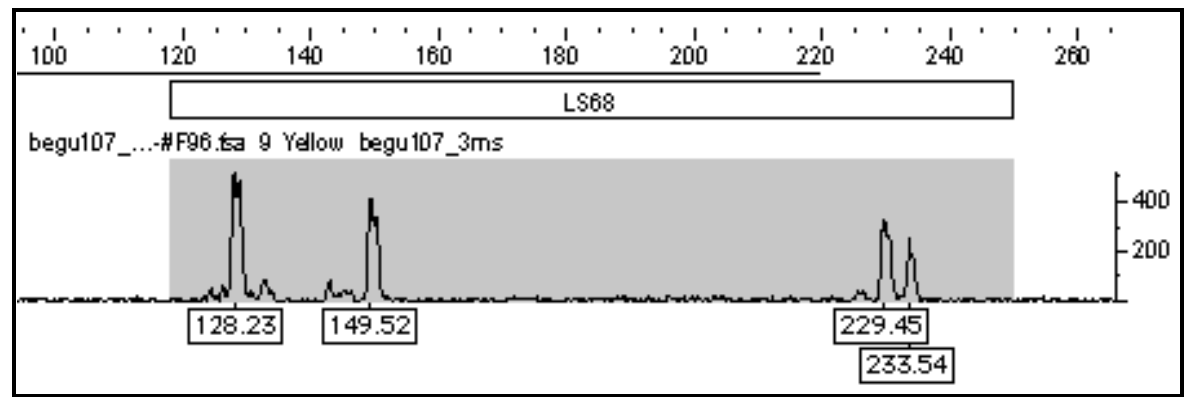

Figure 2: Genotyper software analysis of PCR amplification product for LS 68 microsatellite locus.

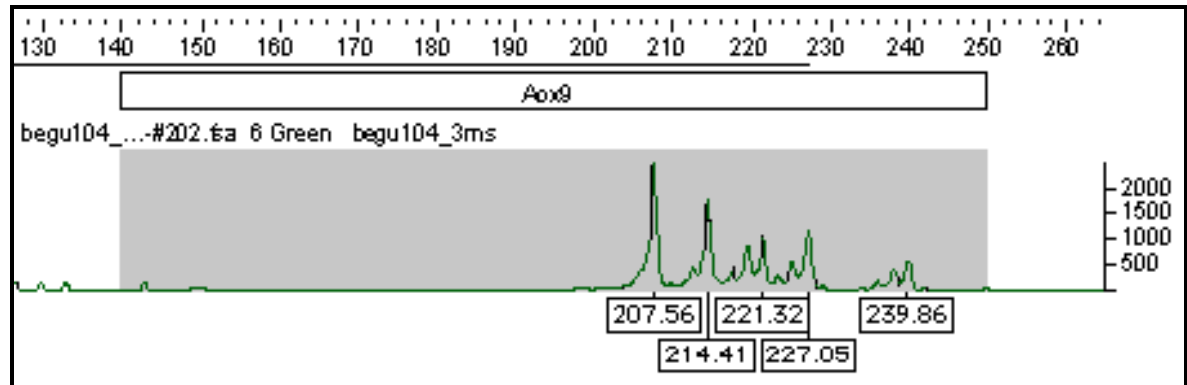

Figure 3: Genotyper software analysis of PCR amplification product for Aox 9 microsatellite locus.

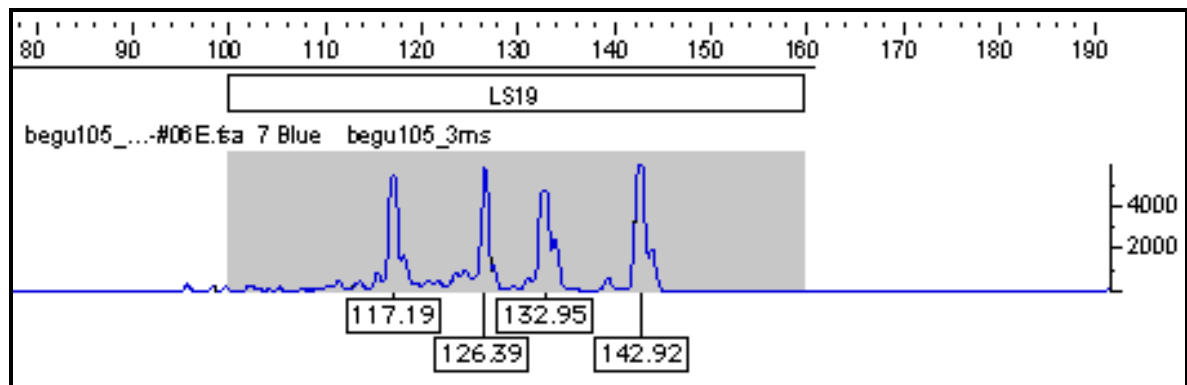

Figure 4: Genotyper software analysis of PCR amplification product for LS 19 microsatellite locus. 


\section{CONCLUSIONS}

The present study showed that sturgeons bred in aquaculture have a low genetic diversity due to an inbreeding effect. Also, from a statistical point of view, it is impossible to analyze polyploid genotypic data together with diploid genotypic data. Therefore, for an estimation of the genetic diversity in hybrids between $A$. baerii and A. gueldestaedtii we propose to isolate and to analyze only the disomic loci in the future.

The need for molecular studies will be increased in the future, thus allowing characterization of stocks and correct identification of individuals.

\section{ACKNOWLEDGEMENTS}

This work was supported by the PN-II-PT-PCCA Project 116/2012 "Genetic evaluation and monitoring of molecular and biotechnological factors that influence productive performance of Danube sturgeon species bred in intensive recirculating systems”.

\section{REFERENCES}

1. Belkhir K., Borsa P., Chikhi L., Raufaste N. and Bonhomme F., 2002 - GENETIX 4.05, logiciel sous Windows TM pour la génétique des populations, Laboratoire Génome, Populations, Interactions, CNRS UMR 5171, Université de Montpellier II, France. (in French)

2. Bemis W. E., Findeis E. K. and Grande L., 1997 - An overview of Acipenseriformes, 25-71, in Birstein V. J., Waldman J. R. and Bemis W. E. (eds), in Sturgeon Biodiversity and Conservation, V, Kluyver Academic Publishers, Dordrecht, Netherlands, 445.

3. Birstein V. J., Hanner R. and De Salle R., 1997 - Phylogeny of the Acipenseriformes: cytogenetic and molecular approaches, 127-155, in Sturgeon Biodiversity and Conservation, Birstein J., Waldman J.R. and Bemis W. E. (eds), Kluwer Academic Publishing, Dordrecht, Netherlands, 445.

4. Estoup A. and Angers B., 1998 - Microsatellites and minisatellites for molecular ecology: theoretical and empirical considerations, 55-86, in Carvalho G (eds), Advances in molecular ecology, IOS Press, Amsterdam, Netherlands, 314.

5. Fontana F., Tagliavini J., Congiu L., Lanfredi M., Chicca M., Laurenti C. and Rossi R., 1998 Karyotypic characterization of the great sturgeon, Huso huso, by multiple staining techniques and fluorescent in situ hybridization, Marine Biology, 132, 495-501.

6. Fopp-Bayat D., 2010 - Microsatellite DNA variation in the Siberian sturgeon, Acipenser baeri (Actinopterygii, Acipenseriformes, Acipenseridae), cultured in a Polish fish farm, Acta Ichthyologica et Piscatoria, 40, 1, 21-25.

7. Forlani A., Fontana F. and Congiu L., 2008 - Isolation of microsatellite loci from the endemic and endangered Adriatic sturgeon (Acipenser naccarii), Conservation Genetics, 9, 461-463.

8. Henderson-Arzapalo A. and King T. L., 2002 - Novel microsatellite markers for Atlantic sturgeon (Acipenser oxyrinchus) population delineation and broodstock management, Molecular Ecology Notes, 2, 437-439.

9. King T. L., Lubinski B. A. and Spidle A. P., 2001 - Microsatellite DNA variation in Atlantic sturgeon (Acipenser oxyrinchus oxyrinchus) and cross-species amplification in the Acipenseridae, Conservation Genetics, 2, 103-119.

10. Matallanas J., 1997 - FIGIS Species Fact Sheets, Species Identification and Data Programme SIDP, in FAO Fisheries and Aquaculture Department (online), Rome, http://www.fao.org/fishery/culturedspecies/Acipenser_baerii/en.

11. McQuown E. C., Sloss B. L., Sheehan R. J., Rodzen J., Tranah G. and May B., $2000-$ Microsatellite analysis of genetic variation in sturgeon: new primers sequences for Scaphirhynchus and Acipenser, Transaction of the American Fisheries Society, 129, 13801388. 
12. Norouzi M. and Pourkazemi M., 2009 - Genetic structure of Caspian populations of stellate sturgeon, Acipenser stellatus (Pallas, 1771), using microsatellite markers, International Aquatic Research, 1, 61-65.

13. Oțel V., 2007 - Atlasul peştilor din Rezervația Biosferei Delta Dunării, Edit. Centrul de Informare Tehnologică Delta Dunării, Tulcea, România, 481. (in Romanian)

14. Pyatskowit J. D., Krueger C., Kincaid H. L. and May B., 2001 - Inheritance of microsatellite loci in the polyploid lake sturgeon (Acipenser fulvescens), Genome, 44, 185-191.

15. Taggart J. B., Hynes R. A., Prodohl P. A. and Ferguson A., 1992 - A simplified protocol for routine total DNA isolation from salmonid fishes, Journal of Fish Biology, 40, 963-965.

16. Tagliavini J., Williot P., Congiu L., Chicca M. and Lanfredi M., 1999 - Molecular cytogenetic analysis of the karyotype of the European Atlantic sturgeon, Acipenser sturio, Heredity, 83, 520525.

17. Timoshkina N., Barmintseva A. E., Usatov A. V. and Mugue N. S., 2009 - Intra-specific genetic polymorphism of Russian sturgeon Acipencer gueldenstaedtii, Russian Journal of Genetics, 45, 1098-1107.

18. Welsh A. and May B., 2006 - Development and standardization of disomic microsatellite loci for lake sturgeon genetic studies, Journal of Applied Ichthyology, 22, 337-344.

19. Welsh A. B., Blumberg M. and May B., 2003 - Identification of microsatellite loci in lake sturgeon, Acipenser fulvescens, and their variability in green sturgeon, Acipenser medirostris, Molecular Ecology Notes, 3, 47-55.

20. Zane L., Bargelloni L. and Patarnello T., 2002 - Strategies for microsatellite isolation: a review, Molecular Ecology, 11, 1-16. 